\title{
IMPACTS OF CORPORATE CULTURE FACTORS ON ORGANISATIONAL COMMITMENT OF EMPLOYEES AT CONCRETE ENTERPRISES IN HO CHI MINH CITY
}

\author{
Van Dung Ha \\ Banking University Ho Chi Minh City, Vietnam. \\ DOI: 10.46609/IJSSER.2020.v05i04.006 URL: https://doi.org/10.46609/IJSSER.2020.v05i04.006
}

\begin{abstract}
This study investigates the impacts of factors of corporate culture on organizational commitment at concrete companies in Ho Chi Minh City. Then, the paper draws some policy implications in order to increase the employee commitment. Both qualitative and quantitative methods are used in the study. A data set of 215 employees who are working at the concrete companies is collected. The SPSS is chosen as a tool for measurement scales, descriptive analysis, EFA analysis, correlation coefficients, and linear multivariate regression model to data analysis. The results indicate that factors of firm culture as reward and recognition, communication, training and development, unique and equity in management policy, working condition all have impacts on organizational commitment of employees at Concrete companies in Ho Chi Minh City. Among these factors, reward and recognition has strongest effect on organizational commitment.
\end{abstract}

Keywords: Organizational culture, Concrete, Commitment, Training, Development, Policy

\section{INTRODUCTION}

Since the participation of Vietnam to World Trade Organization (WTO), Vietnamese enterprises have more opportunities to do business in international market. Many foreign firms have invested to Vietnam and have absorbed many employees. However, the integration creates a lot of challenges to domestic enterprises as well as domestic workers. Highly competition market requires enterprises improve their management quality as well as employment quality. High quality employees are needed and the employee commitment is also important. This is the important issue for all enterprises. One enterprise can develop if only if there are high quality employees who can devote their ability and skills to firm success (Zain et al., 2009). To do this, this enterprise has to build up a professional corporate culture which is distinct and which has a friendly working environment. Thus, it can foster employees working efficiently and committing 


\section{International Journal of Social Science and Economic Research}

ISSN: $2455-8834$

Volume: 05, Issue: 04 "April 2020"

themselves to their enterprises (Mayer et al., 2010). That is the significant result which corporate culture can create and this would be the important factor determining the corporate success. The way the enterprises behave to their employees is similar to that of employees' behavior to the customers, and the enterprise's success is determined by the commitment and effectiveness of employees (Flamholtz \& Randle, 2000; Harwiki, 2016).

In Vietnam, research studying the impacts of corporate culture on employee commitment are still inceptive. Most studies focus on fields of information technology, services or education while concrete industry has until now no relating research. This research, thus, can fulfill the gap in the literature on the impacts of corporate culture on employee commitment, and then some management implications would be raised in order to increase the commitment of employees in concrete firms in Vietnam.

The rest of the paper is organized as follows. The second section will introduce the literature review while the methodology will be discussed in section three. The forth section will analyze the empirical results. Section 5 will conclude the paper.

\section{LITERATURE REVIEW}

Corporate culture is differently defined in the literature. O'Reilly and Chatman (1996) state that corporate culture mentions system of value and allowance which is shared and which is used to identify the suitable attitudes and behaviors of its members. Schein (2009) proposes that corporate culture is an aggregation of basic values, standards, and beliefs which are accumulated in the interaction process with outside environment as well as integration with inside environment. These values are transferred to its members as a whole to form a united thinking and generate the same methodology to solve the members' problems. Corporate culture a system of thought, value, belief, awareness, and methodology which all members of the corporate agree and which influence to each member's awareness and action (Ooi and Arumugam, 2006).

In their model, Recardo and Jolly (1997) use 8 variables measure the corporate culture. They are communication, training and development, reward and recognition, group working, risk acceptance, fair and unique management, effective decision, and planning. These 8 elements all affect employee commitment. Among these factors, group working, training and development, communication in organizations, and reward and recognition are confirmed to have impacts on organization commitment (Boon \& Arumugam, 2006). Using the data from 37 logistics companies in Marmara region of Turkey, Acar (2012) investigate the impacts of corporate culture on organizational commitment. A sample size of 344 employees in logistics industry has been utilized. The results of the study show that there is a positive impact of corporate culture on organizational commitment of employees in Turkish logistics industry. 
Utilizing the literature review, the paper proposes a research model to estimate the impacts of corporate culture on organizational commitment in concrete enterprises in Ho Chi Minh City as follows:

Figure 1: Research model

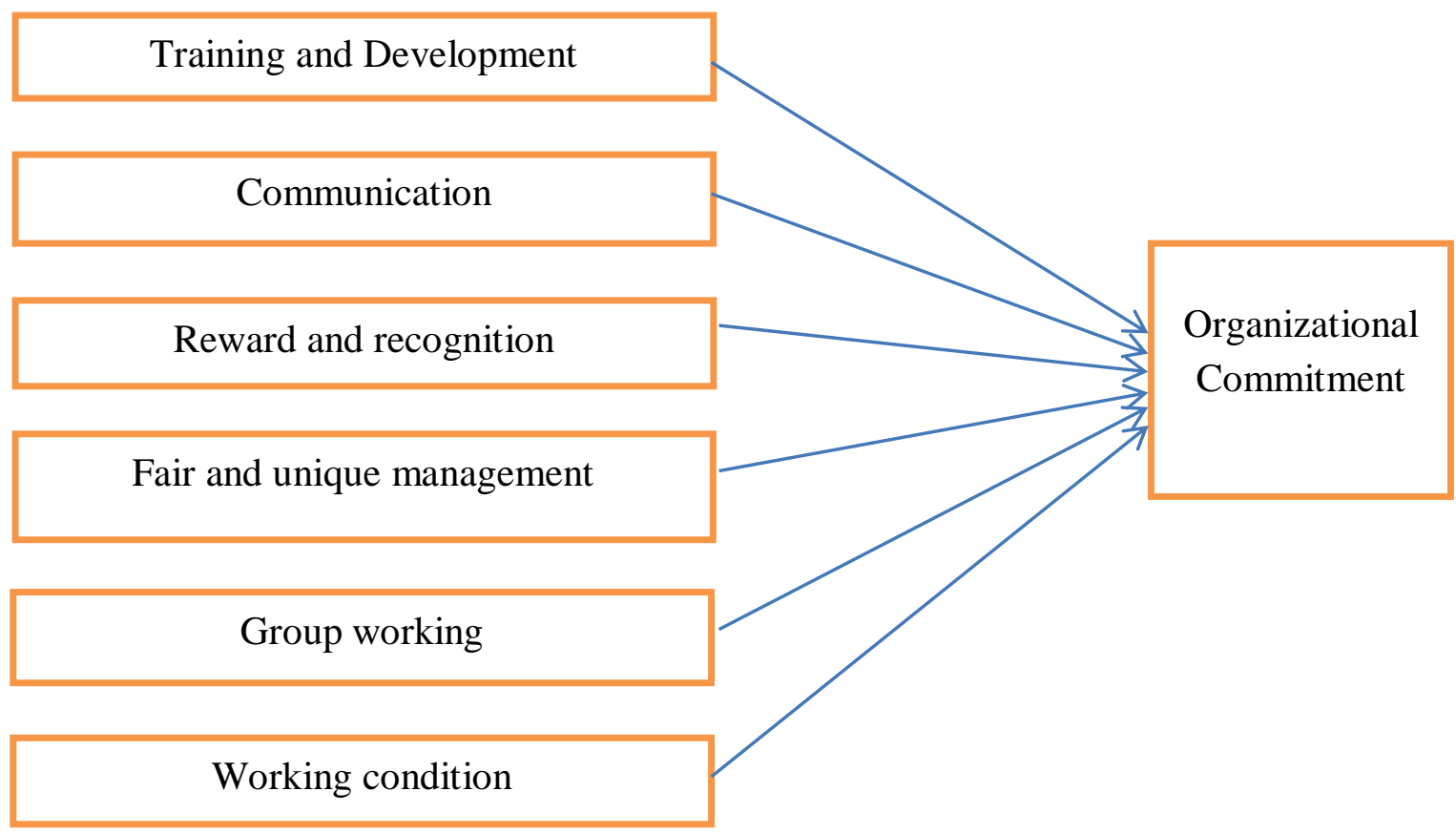

Source: Author's summary

\section{RESEARCH METHODOLOGY}

The paper employs both qualitative method and quantitative method to estimate the impacts of corporate culture on organizational commitment concrete enterprises in Ho Chi Minh City. Components and measurement scales are taken from previous relevant studies. Initially, in qualitative method, five variables including training and development, communication, Reward and recognition, fair and unique management, and group working are taking in to group discussion. There are 6 experts who are working in human resource department of 4 concrete companies taking part in the group discussion. These five factors get generally agreement among experts. Additionally, there is another argument that employees who work in concrete industry always work in unhealthy environment, especially facing dust. Thus, another variable which measures working environment should be added. After discussion, working condition variable is added to the research model, and totally there are 6 independent variables. 
After the research model is finalized, the questionnaire which includes 37 components in 7 variables is delivered to employees of 15 concrete companies in Ho Chi Minh City. Likert scale is used to measure the components and variables. The study uses the non-probability sampling method. Totally, there are 265 questionnaires delivered and 215 to receive. The research employs SPSS software to test research hypotheses via measurement scales, descriptive analysis, EFA analysis, correlation coefficients, and linear regression model.

\section{EMPIRICAL RESULTS}

\subsection{Cronback's Alpha analysis}

Table 1: Cronbach's Alpha coefficients of organizational culture variables

\begin{tabular}{|l|l|c|}
\hline \multicolumn{1}{|c|}{ Variables } & \multicolumn{1}{|c|}{ Components } & Sig. \\
\hline Group working (GW) & GW1, GW2, GW3, GW4 & 0.810 \\
\hline Communication (COM) & COM1, COM2, COM3, COM4, COM5 & 0.877 \\
\hline Training and Development (T\&D) & T\&D1, T\&D2, T\&D3, T\&D4, T\&D5 & 0.874 \\
\hline Reward and Recognition (R\&R) & R\&R1, R\&R2, R\&R3, R\&R4, R\&R5, R\&R6 & 0.851 \\
\hline Fair and Unique management (FUM) & FUM1, FUM2, FUM3, FUM4, FUM5 & 0.847 \\
\hline Working Condition (WOC) & WOC1, WOC2, WOC4, WOC5 & 0.822 \\
\hline Organization Commitment (OC) & OC1, OC2, OC3, OC4, OC5, OC6 & 0.814 \\
\hline
\end{tabular}

\section{Source: Author's calculation}

Initial analysis shows that the component T\&D6 belonging to training and development variable has corrected item-total correlation smaller than 0.4 . This indicates that T\&D6 component should be eliminated. Another component will be deleted is WOC3. Other components fulfill the requirement and can be used for further analysis.

\subsection{EFA analysis}

Table 2: KMO and Barlett's test

\begin{tabular}{|c|c|c|}
\hline \multicolumn{2}{|c|}{ KMO } & 0.653 \\
\hline \multirow{3}{*}{ Bartlett's test of sphericity } & Approx. Chi-Square & 6721.314 \\
\cline { 2 - 3 } & $\mathrm{df}$ & 351 \\
\cline { 2 - 3 } & Sig. & 0.000 \\
\hline
\end{tabular}

Source: Author's calculation 
$\mathrm{KMO}$ and Barlett's test indicate that $\mathrm{KMO}$ coefficient equals to 0.653 and this satisfies $0.5 \leq$ $\mathrm{KMO} \leq 1, \mathrm{KMO}$. Bartlett's test of sphericity with the significant level of 0.000 implies that components are correlated and data can be used for EFA analysis. Factor loading is also greater than 0.5 so the scale is significant.

Table 3: Rotated Component Matrix

\begin{tabular}{|c|c|c|c|c|c|c|c|}
\hline \multirow[b]{2}{*}{ Components } & \multicolumn{6}{|c|}{ variable } & \multirow{2}{*}{$\begin{array}{c}\text { Variable's } \\
\text { name }\end{array}$} \\
\hline & 1 & 2 & 3 & 4 & 5 & 6 & \\
\hline T\&D3 & 0.823 & & & & & & \multirow{5}{*}{$\begin{array}{l}\text { Training and } \\
\text { Development }\end{array}$} \\
\hline T\&D5 & 0.840 & & & & & & \\
\hline T\&D1 & 0.798 & & & & & & \\
\hline T\&D4 & 0.771 & & & & & & \\
\hline T\&D2 & 0.785 & & & & & & \\
\hline R\&R6 & & 0.877 & & & & & \multirow{6}{*}{$\begin{array}{l}\text { Reward and } \\
\text { recognition }\end{array}$} \\
\hline $\mathrm{R} \& \mathrm{R} 2$ & & 0.820 & & & & & \\
\hline $\mathrm{R} \& \mathrm{R} 1$ & & 0.714 & & & & & \\
\hline $\mathrm{R} \& \mathrm{R} 4$ & & 0.645 & & & & & \\
\hline R\&R5 & & 0.612 & & & & & \\
\hline R\&R3 & & 0.585 & & & & & \\
\hline FUM3 & & & 0.910 & & & & \multirow{4}{*}{$\begin{array}{c}\text { Fair and Unique } \\
\text { management }\end{array}$} \\
\hline FUM5 & & & 0.889 & & & & \\
\hline FUM2 & & & 0.884 & & & & \\
\hline FUM1 & & & 0.784 & & & & \\
\hline COM5 & & & & 0.814 & & & \multirow{5}{*}{ Communication } \\
\hline COM1 & & & & 0.745 & & & \\
\hline COM4 & & & & 0.774 & & & \\
\hline COM2 & & & & 0.675 & & & \\
\hline COM3 & & & & 0.665 & & & \\
\hline GW1 & & & & & 0.914 & & \\
\hline
\end{tabular}


International Journal of Social Science and Economic Research

ISSN: 2455-8834

Volume: 05, Issue: 04 "April 2020"

\begin{tabular}{|c|c|c|c|c|c|c|c|}
\hline GW4 & & & & & 0.858 & & \multirow[t]{3}{*}{ Group working } \\
\hline GW2 & & & & & 0.845 & & \\
\hline GW3 & & & & & 0.751 & & \\
\hline WOC2 & & & & & & 0.881 & \multirow{4}{*}{$\begin{array}{l}\text { Working } \\
\text { condition }\end{array}$} \\
\hline WOC5 & & & & & & 0.858 & \\
\hline WOC4 & & & & & & 0.797 & \\
\hline WOC1 & & & & & & 0.662 & \\
\hline Eigenvalues & 6.650 & 3.448 & 2.473 & 2.411 & 2.047 & 1.734 & \\
\hline \multicolumn{5}{|c|}{ Total variance explained } & \multicolumn{3}{|c|}{$67.76 \%$} \\
\hline
\end{tabular}

Source: Author's calculation

The results of the rotated component matrix show that Eigenvalues of factors are all greater than 1 and significant. Principle component analysis and Varimax generate 6 factors from 28 components with the total variance explained of $67.76 \%$.

\subsection{Correlation}

Table 4: Pearson correlation

\begin{tabular}{|c|c|c|c|c|c|c|c|c|}
\hline & & $\mathrm{OC}$ & $\mathrm{R} \& \mathrm{R}$ & $\mathrm{T} \& \mathrm{D}$ & CBNQ & GI & GW & WOC \\
\hline \multirow[t]{3}{*}{$\mathrm{OC}$} & $\begin{array}{l}\text { Pearson } \\
\text { Correlation }\end{array}$ & 1 & $.572^{* *}$ & $0.601^{\text {** }}$ & $0.256^{* *}$ & $0.607^{* *}$ & $0.250^{* *}$ & $0.241^{* *}$ \\
\hline & Sig. (2-tailed) & & 0.000 & 0.000 & 0.000 & 0.000 & 0.000 & 0.000 \\
\hline & $\mathrm{N}$ & 215 & 215 & 215 & 215 & 215 & 215 & 215 \\
\hline \multirow[t]{3}{*}{$\mathrm{R} \& \mathrm{R}$} & $\begin{array}{l}\text { Pearson } \\
\text { Correlation }\end{array}$ & $.572^{* *}$ & 1 & $0.408^{* *}$ & $0.198^{* *}$ & $0.422^{* *}$ & $0.150^{*}$ & 0.037 \\
\hline & Sig. (2-tailed) & 0.000 & & 0.000 & 0.004 & 0.000 & 0.028 & 0.631 \\
\hline & $\mathrm{N}$ & 215 & 215 & 215 & 215 & 215 & 215 & 215 \\
\hline \multirow[t]{3}{*}{$\mathrm{T} \& \mathrm{D}$} & $\begin{array}{l}\text { Pearson } \\
\text { Correlation }\end{array}$ & $0.601^{* *}$ & $0.408^{* *}$ & 1 & 0.115 & $0.435^{* *}$ & $0.145^{*}$ & $0.144^{*}$ \\
\hline & Sig. (2-tailed) & 0.000 & 0.000 & & 0.081 & 0.000 & 0.033 & 0.049 \\
\hline & $\mathrm{N}$ & 215 & 215 & 215 & 215 & 215 & 215 & 215 \\
\hline
\end{tabular}


International Journal of Social Science and Economic Research

ISSN: $2455-8834$

Volume: 05, Issue: 04 "April 2020"

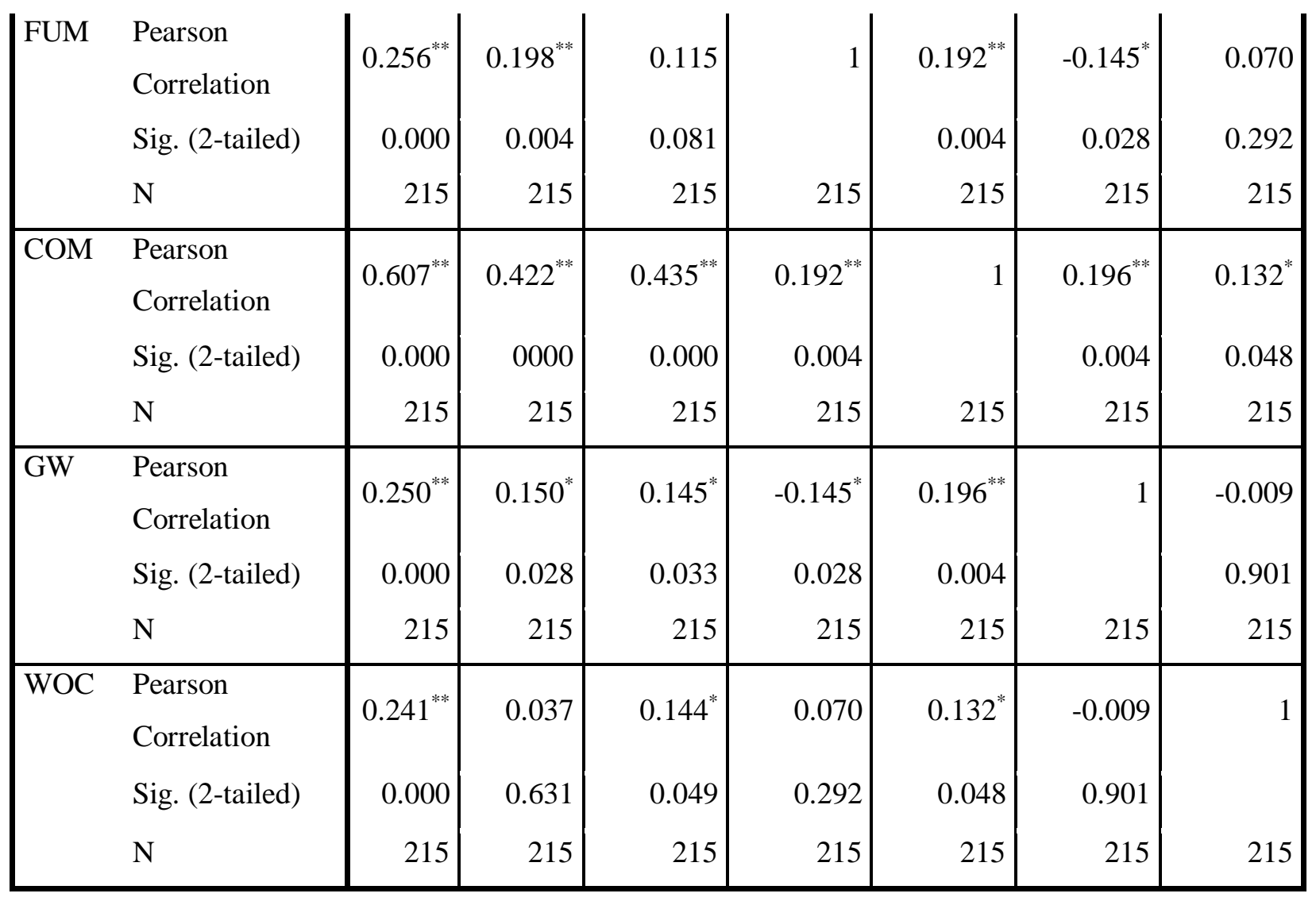

Source: Author's calculation

The Pearson correlation results show statistically significant relation between independent variables and organizational commitment. These relations are positive implying an increase in independent factor would be accompanied by an increase in organizational commitment.

\subsection{Multivariate regression}

The results of multivariate regression are in the table 6 .

Table 6: Estimation results

\begin{tabular}{|c|l|c|c|c|c|c|c|c|}
\hline \multirow{2}{*}{ Model } & \multicolumn{2}{|c|}{$\begin{array}{c}\text { Unstandardized } \\
\text { coefficient }\end{array}$} & $\begin{array}{c}\text { Standardized } \\
\text { coefficient }\end{array}$ & t & Sig. & \multicolumn{2}{|c|}{$\begin{array}{c}\text { Collinearity } \\
\text { statistics }\end{array}$} \\
\cline { 3 - 9 } & B & S.E. & Beta & & & Tolerance & VIF \\
\hline \multirow{2}{*}{1} & (Constant) & -0.445 & 0.245 & & -1.804 & 0.073 & & \\
\cline { 2 - 9 } & R\&R & 0.285 & 0.053 & 0.276 & 5.534 & 0.000 & 0.743 & 1.348 \\
\hline
\end{tabular}


International Journal of Social Science and Economic Research

ISSN: 2455-8834

Volume: 05, Issue: 04 "April 2020"

\begin{tabular}{|l|l|r|r|r|r|r|r|l|}
\hline T\&D & 0.255 & 0.041 & 0.313 & 6.284 & 0.000 & 0.742 & 1.351 \\
\cline { 2 - 8 } FUM & 0.108 & 0.034 & 0.127 & 2.853 & 0.005 & 0.908 & 1.104 \\
\hline COM & 0.275 & 0.049 & 0.278 & 5.637 & 0.000 & 0.706 & 1.415 \\
\hline GW & 0.099 & 0.035 & 0.124 & 2.825 & 0.005 & 0.915 & 1.094 \\
\hline WOC & 0.152 & 0.051 & 0.133 & 3.157 & 0.002 & 0.967 & 1.033 \\
\hline
\end{tabular}

Source: Author's calculation

The equation is expressed as following:

$\mathrm{OC}=-0.445+0.285 \mathrm{R} \& \mathrm{R}+0.255 \mathrm{~T} \& \mathrm{D}+0.108 \mathrm{FUM}+0.275 \mathrm{GI}+0.099 \mathrm{GW}+0.152 \mathrm{WOC}+\mathrm{e}_{\mathrm{i}}$

According to the estimation results, all coefficients are statistically significant. So, variables of corporate culture have positive impacts on organizational commitment. There are factors including training and development, communication, Reward and recognition, fair and unique management, and group working affecting organizational commitment of employees in concrete companies in Ho Chi Minh City. These results support the arguments of some previous studies (Recardo and Jolly, 1997; Boon \& Arumugam, 2006, Korall et al., 2018). In addition, new factor in this research, working condition, also has statistically significant effects on employee commitment.

Among these determinant, training and development seems to have largest impacts on the commitment. It implies that employees put their attention on the opportunities to have training as well as chances to develop themselves. This may reflect the Vietnamese culture in general, in which people pay resources on education and training. The group working is proved to have the smallest impacts on organizational commitment in concrete enterprises in Ho Chi Minh City.

\section{CONCLUSION AND IMPLICATIONS}

\subsection{Conclusion}

The organizational commitment is found to have important role for enterprises in the literature while corporate culture has positive impacts on organizational commitment. Firm performance largely depends on the work outcomes of their employees who are committed to their organizations. Most studies agree that corporate culture includes six components including training and development, communication, reward and recognition, fair and unique management, and group working. This study examines the effects of factors of corporate culture on organizational commitment in concrete enterprises in Ho Chi Minh City. Using 215 observations from 15 concrete firms, the study uses measurement scales, descriptive analysis, EFA analysis, 
International Journal of Social Science and Economic Research

ISSN: $2455-8834$

Volume: 05, Issue: 04 "April 2020"

correlation coefficients, and linear regression model to analysis. The results reveal that training and development, communication, reward and recognition, fair and unique management, and group working which belong to corporate culture have positive impacts on organizational commitment of employees in concrete industry. Furthermore, working condition, which measures the unhealthy working environment of concrete industry is added to the model and this variable is also positively related to organizational commitment of employees.

\subsection{Policy implication}

\section{Reward and recognition}

Reward policy should be transparent and clear, and should be announced to everyone in the enterprise. The firms should have key performance indicator for paying salary as well as innovation should be rewarded. In addition, firms should pay attention to their salary policy, which can promote working and attract more skilled labor. Developing and maintaining effective labor force must be in priority because they are forces and strength of the firms.

\section{Communication}

Communication within the enterprise can enhance organizational commitment. Monthly, quarterly, or yearly meetings can help managers understand what employees are thinking and find a way for best co-operation. Information should be regularly shared among departments. Changes in any policy should be delivered to employees to capture the main points of their benefits as well as their duties. Understanding well can promote the commitment. Friendly working environment is also needed when employees work together and may help together. In some cases, people do not want to switch their job due to their familiarity to the old job even though new job maybe more attractive and the salary can be higher.

\section{Training and development}

This is the strongest factor affecting organizational commitment. Each position should be qualified and effectiveness should be evaluated. Training program should be constructed basing on the training demand of employees and positions. Training plans should clearly define objectives, scope, fields, and costs. During training process, monitoring and controlling are important for future plans. After training, valuation should be done in order to ensure that knowledge and skills in training program are appropriately applied in the enterprises. The whole training process should be carefully monitored and recorded. Increasing training can be considered a benefit for employees.

\section{Fair and unique management}




\section{International Journal of Social Science and Economic Research}

ISSN: $2455-8834$

Volume: 05, Issue: 04 "April 2020"

Fair and unique policy should be applied in all fields of firm operation. Everyone is equally considered when they get success or failure. To do so, managers have to build up an effective evaluating system, which can apply for each position in the enterprise. The enterprise has to deal with every feedback from their employees and quickly solve any problem of their system.

\section{Group working}

Firstly, group working can promote employees share knowledge and increase cooperation within the organization. Group working can increase employee knowledge, skills, and experience which in turn promote the effectiveness of working. Closer contact within group may enhance the understanding among employees and thus increase their commitment.

Furthermore, firms need to increase team building across departments via outside activities like karaoke, sports, and other outdoor activities. These activities can increase employee's site experience and thus building working connection. To enhance group working, firms should have the evaluating procedure for each team and team members.

\section{Working condition}

Enterprises in concrete industry must ensure full working equipment, working safety, friendly working environment. A favorable working environment may help employees utilize their labor to get highest effectiveness as well as set up a good connection to other employees and the managers. Because in concrete industry, dust is inevitable, the working environment should minimize dust and working places should be cleaned every day. Feedback of working conditions from employees should be regularly collected in order to have adequate solutions and adjustment which can promote the employee commitment and thus encouraging the firm development.

\section{REFERENCES}

Acar, A. Z. (2012). Organizational Culture, Leadership Style and Organizational Commitment in Turkish Logistics Industry. Procedia-Social and Behavior Sciences, 58, 217-226.

Boon, O. K., \& Arumugam, V. (2006). The Influence of Corporate Culture on Organizational Commitment: Case Study of Semiconductor Organizations in Malaysia. Sunway Academic Journal, 3, 99-115.

Flamholtz, E., \& Randle, Y. (2000). Growing Pains: Transitioning from an Entrepreneurship to a Professionally Managed Firm. San Francisco: Jossey-Bass. 
International Journal of Social Science and Economic Research

ISSN: 2455-8834

Volume: 05, Issue: 04 "April 2020"

Harwiki, W. (2016). The Impacts of Servant Leadership on Organization Culture, Organizational Commitment, Organizational Citizenship Behavior (OCB), and Employee Performance in Women Cooperatives. Procedia-Social and Behavior Sciences, 219, 283-290.

Korall, A. M. B., Loughin, T. M., Feldman, F., Cameron, I. D., Leung, P. M., Sims-Gould, J., Godin, J., \& Robinovicht, S. N. (2018). Determinants of Staff Commitment to Hip Protectors in Long-term Care: A Cross-Sectional Survey. International Journal of Nursuring Studies, 82, 139-148.

Mayer, J. P., Hecht, T. D., Gill, H., \& Toplonoytsky, L. (2010). Person-organization (culture) fit and Employee Commitment under conditions of organizational change: a longitudinal study. Journal of Vocational Behavior, 76(3), 458-473.

Ooi, K. B., \& Arumugam, V. (2006). The Influence of Corporate Culture on Organization Commitment: Case Study of Semiconductor Organization in Malaysia. Sunway Academic Journal, 3, 99-115.

O'Reilly, C. A., \& Chatman, J. A. (1996). Culture as social control: Corporations, cults, and commitment. In B. M. Staw \& L. L. Cummings (Eds.), Research in organizational behavior: An annual series of analytical essays and critical reviews, 18, 157-200.

Recardo, R., \& Jolly, J. (1997). Organizational Culture and Teams. S.A.M. Advanced Management Journal, 62 (2), 4-7.

Schein, E. H. (2009). Warren Bennis book. The corporate culture survival guide (New and rev. ed.). Jossey-Bass.

Zain, Z. M., Ishak, R., \& Ghani, E. K. (2009). The Influence of corporate culture on organizational commitment: A study on a Malaysian listed company. European Journal of Economics, Finance and Administrative Sciences, 17, 17-26. 